\title{
An overview of transboundary haze studies: The underlying causes and regional disputes on Southeast Asia region
}

\author{
Ku Mohd Kalkausar Ku Yusofa, Azman Azida,*, Mohd Saiful Samsudinª , Mohd Asrul Jamalanib \\ a Faculty Bioresources and Food Industry, Universiti Sultan Zainal Abidin, Besut Campus, 22200 Besut, Terengganu, Malaysia \\ ${ }^{b}$ Faculty of Environmental Studies, Universiti Putra Malaysia (UPM), 43400 Serdang, Selangor, Malaysia \\ * Corresponding author: azmanazid@unisza.edu.my
}

Article history

Received 11 July 2017

Accepted 6 December 2017

\begin{abstract}
Air pollution is now ranked as the ninth worst scenario globally and is expected to be the most serious global issue by the year 2050. The objective of this study is to get information regarding transboundary haze phenomenon blanketing the Southeast Asia that has been happened for decades ago. Various techniques such as qualitative and quantitative techniques have been applied to get the informative input detailed out by previous researchers. The finding shows that that the smoky haze occurred in the dry season, which at this point, the activities of cleaning and ground maintenance being carried out by Indonesian farmers. Indonesia is one of the countries drastically affected by deforestation process where their forest loss is $2 \% \mathrm{yr}-1$ which is equal to 1.9 million ha each year. The establishment of ASEAN in 2002 would be a turning point in addressing on more reliance on prevention and cooperation than establishing a liability regime or adopting legal instruments to protect the environment. However, the reflection of so-called 'ASEAN Way', which preferred on non-interference in other states has inhibited the reliance on strong regional efforts in executing a more effective action in order to address and combat the transboundary haze pollution in Southeast Asia.
\end{abstract}

Keywords: Haze phenomenon; air pollution; transboundary pollution; smoky haze; deforestation

\section{INTRODUCTION}

The first ever reported case in West Coast of Peninsular Malaysia regarding haze issues was in 1960's but this controversial subject has only been converted into scientific research in early 1980's. This haze has caused visibility to deteriorate heavily that an aircraft flying from London missed its destination to Kuala Lumpur, and overflow to Singapore. The haze's concentration, duration, extensiveness, has a number of social and economic impact, human's health is equally affected. The 1994 and 1997's record of pollution from haze were incomparable in terms of its adverse impact. From that incidence alone, Malaysia lost about \$US 600 million and \$US 700 million from health and transportation industries respectively (Nichol, 1997). The estimation of the area burned reported in the province of Kalimantan from August 1997 until July 1998 was about 5 million ha and their direct and indirect losses were reported around USD $8.7-9.2$ billion (Field et al. 2004).

Before the 21 st century, between the 80 s and 90 s, thick smoky haze smothered Southeast Asia region during the months of AugustSeptember 1982, September 1983, September 1987, August 1990, August-September 1991, August-October 1994, August-October 1997 and February-May 1998 (Betha et al. 2013). The number of haze episodes stated earlier was due to uncontrolled large-scale deforestation in Sumatra and Kalimantan. Therefore, it has led various part of Indonesia's forests to experienced widespread fires in recent decades (Herawati and Santoso, 2011). The consequence from mega forest fires in Indonesia created serious disagreement among the affected countries especially Malaysia, Singapore and Brunei in term of transboundary atmospheric pollution (Hayasaka et al. 2014), Indonesia' lack effectiveness in her existing regulation and efficiency of forest fires combat. Anthropogenic activity was not the only aspect in forest fires. Mudiyarso et al. (2014), Saharni et al. (2014) and Van der Werf et al. (2008) in their studies stressed out that the combination of intermonsoon dry season in June to September, Indian Ocean Dipole, Madden-Julian Oscillation and El Nino Southern Oscillation (ENSO) exacerbated wild forest fires in Indonesia and resulting in prolonged and persistent of haze emission to most Southeast Asia (Aghamohammadi et al. 2011).

\section{EXPERIMENTAL}

Various techniques already have been applied based on previous works of scholars on their particular field areas. Those techniques comprise of qualitative and quantitative approaches, and they were generally focused on transboundary atmospheric pollution studies, satellite observation, simulation and numerical models (mostly on weather and haze trajectories), international law and legislative, continuous and partially on-site monitoring, and also the statistical analysis. In this study, we compiled the informative input detailed out by previous researchers, thus we are emphasizing on underlying features (economic, deforestation \& anomalous weather climate) of the trans-boundary haze in Southeast Asia's region. On top of that, the comparisons were made based on real occurrence from other studies throughout the world. Next, regional multilateral responsibilities and disputes were on addressing the trans-boundary issue and finally, the abatement measures were presented. As additional information, Indonesia, Malaysia, and Singapore were chosen to be discussed in this 
paper based on a vital criterion; haze's frequency, extensiveness, and duration for the past two decades.

\section{RESULTS AND DISCUSSION}

\section{The fundamental disagreements: History and present situation}

The 1992 Rio Declaration on Environment and Development has declared three principles (Palanissamy, 2013); (1) Nations have the right to exploit their own resources, but without causing environmental damage beyond their borders, (2) The polluter should, in principle, bear the cost of pollution, and (3) Sustainable development requires better scientific understanding of the problems. Nations should share knowledge and technologies to achieve the goal of sustainability. If we focus more on the first two principles, The Rio Declaration has stressed out on how nations should observe the law and order by not easily committing any liabilities to neighboring countries. Despite the international agreement and environmental related declaration, the trans-boundary air pollutions are remained as environmental agenda in developed countries like in Europe and the United States and developing countries especially in Southeast Asia (Nurhidayah, 2011). Both regulatory and scientific viewpoint has already been discussed, however, it just ends with obscure explanation due to continuous increasing population, expanding economies, and urbanization (Balasubramanian, 2003).

Before proceeding into the trans-boundary haze fundamental issues there is the need to understand the meaning of haze i. - As defined by (DOE, 2015), the haze was seen as a bizarre weather phenomenon due to a higher amount of suspended particulate which cannot be seen by naked eye either in liquid, smoke or vapor forms in the atmosphere. Haze may also be defined as the presence of fine particle at high concentration, where it can cause barely visible for naked eye (Soleiman et al. 2003). In fact, haze could create visibility's impairment with less than $10 \mathrm{~km}$ (Keywood et al. 2003); (Wang et al. 2014) whilst the relative humidity (RH) is less than $75 \%$ (Park et al. 2013). In the 1980s, particulate matter was studied and has been found to be the major pollutant in a haze. The most interesting part of haze is its own specific characteristics. Haze was found to be strongly influenced by meteorological variable (Cattau et al. 2016) and associated with heavy metal (Noreal et al. 2013), atmospheric pollutant and greenhouse gasses (Davies and Unam, 2009) which could produce hostile implications on ecosystem especially to biota. Haze formation is in micrometer $(\mu \mathrm{m})$ and it ranges within $0.1-1.0 \mu \mathrm{m}$ in diameter.

In Southeast Asia, numerous argumentation sessions among scholars (Dotse et al. 2016) on trans-boundary haze in terms of the definition (Rahman, 2013), characteristics (Ryu et al. 2007), historical records (Shi et al. 2015), the implication to ecosystem (Wiwatanadate and Liwsrisakun, 2011), which indirectly attributed to chemical deposition (Ayers et al. 2007; Hu et al. 2003). The trans-boundary issue was not only blanketed Southeast Asia, it even experienced decades ago in Korea and Japan or even in Taipei due to China's rapid development (Lee et al. 2006; Lee et al. 2013; Oh et al. 2015). For records, the year of 1983, 1990, 1991, 1994, 1997, 1998, 2002, 2003, 2004 and 2006 have been reported as haze's year for Southeast Asia and newly it becoming an annual occurrence (Velasco and Rastan, 2015) and their causes and effects have been widely reported (Zaccone et al. 2014). Historically, the worst catastrophic incidents occurred in 1994 and 1997/1998 (Muraleedharan, 2000). The earlier studies suggested that air pollutions can be transported by long-range trans-boundary processes (Lin et al. 2014; Kim, 2011; Koe et al. 2001) across oceans, continent and countries (Wang et al. 2014), depending on continuously changes in prevailing weather condition (Kim et al. 2014).

Haze is strongly linked to dry deposition, prevailing weak-stagnant wind's condition and occasionally exacerbated with extremely adverse weather condition. For Asia equatorial regions like Indonesia, Malaysia, Brunei and Singapore, the South-West (April to September) and North-East (November to February) monsoonal season is dominating. Despite haze's occurrences in South-West monsoon, typically it occurs during July-September (Abas et al. 2004) and sometimes up to October and November (As-syakur et al. 2014). For
Sumatra's east coast farmer, only during the dry season through Southwest monsoon, they would have a best opportunity to clear terrestrial land for agricultural purposes (Hyer and Chew, 2010). In spite of prevailing winds, the meteorological factor such as emission, transportation, chemical transformation via wet and dry deposition strongly influenced the haze characteristics (Demuzere et al. 2008). Furthermore, the spatial and temporal compartments of wind condition are characterized by differentiation of thermal and surface coarseness (Payus et al. 2013).

Southeast Asia's Haze, derived by Indonesia's economy since 1930 , right after the colonization of Indonesia by Netherland, the centralization of human settlement in Java was a real challenge compared to those in Sumatra, Kalimantan, and Sulawesi. While heavily populated, Java lacks efficient and effective cultivation and domestication capacity due to unavailability of land, hence resulting in a wide scale deforestation process. It was reported that in Java, the population density was about 313.2 persons per $\mathrm{km} 2$. To explore the forest, the farmer or the logger used a simple cutting method, (Tacconi and Vayda, 2006) and it seems not giving any heavy impact on deforestation process. Yet, started in the mid-1960s, with the huge demand from Japan and China paper mills industries, mixed up with an introduction of Indonesian's enactment regulation especially in Forestry Law and then added up with some incentives, it has drawn attention from logging concessions to be established in Indonesia (Kartawinata et al. 2001). The deforestation only became a priority issue when the people suffered from poverty, high rise of the inflation rate and lived in the chaotic economic situation due to instability in Indonesia's economy (Tsujino et al. 2016). Due to unpredictability in economic circumstances, the best resolution to regenerate Indonesia's revenue was by sacrificing their natural rainforest to logging concessions. Yet, their decisions were right, the annual timber production has shown a rapid growth (Tsujino et al. 2016).

Notwithstanding of rally exports to East Asia region, Indonesia started to reduce their round wood production in 1980 and finally banned in 1985. On the other hand, in the early 1990s, the Indonesian government has initiated a policy to reduce overpopulated hierarchy in Java Island that being called as "Trans-migratory Programme". The main objective of trans-migratory is to encourage families or personnel to move out from Java to outer islands and it was hoping that the program will help them in reducing the dense population, poverty, and land degradation (Sunderlin and Resosudarmo, 1996). Indonesia's government has achieved their goal by transporting most of their people to the outer island (Kalimantan and Sumatra), but they overlooked a serious incoming issue; Deforestation. The incursion of trans-migrants is directly proportional to land deforestation. Deforestation lead to forest fires and forest fires will finally lead to infertility or land degradation disputes. As trans-migrants, they unquestionably need to adapt to new environment and socio-economy. To survive, they have to explore and it was actually exploiting the natural resources (e.g: rainforest, river, wildlife, etc) as a new option for cultivationdomestication, and those issues were frequently questioned by NGOs. As a result, in the midst of the 1980s, an international Non-Government Organizations (NGOs) deliberated as Trans-migratory program was promoting deforestation in Sumatra, Kalimantan and Sulawesi Sunderlin and Resosudarmo, 1996).

For the last two decades, Japan has imported more than 10 million $\mathrm{m}^{3}$ round-wood for their paper mills industries. Whilst, China has imported the round-wood for domestically demand from furniture industries. After the production of round-wood has been banned in 1985, the deforestation scenario began to change. Furthermore, Indonesia struggled to meet the international standard, whilst at the same time, their sustainable timber production declined. With the continuation of illegal concessions, it was easy to export the production with the lower prices. About the early 1990s, Indonesia liberalized their laws regarding foreign investment. Despite the world's oil price fell in the 1980s, the demand from palm oil sector was $7 \%$ per annum. With the higher demand in palm oil sector, Indonesia has introduced a few key initiatives to stimulate oil palm plantation development. Casson (2000) has revealed of Indonesia's proactive action in promoting palm oil plantation as economic-driven in the 21 st century. For example, Indonesia has revised and lowered their interest rates, the changes in 
the regulation system, restructuring of their debt scheme, the higher demand for palm oil commodity, the land's availability, export tax reduction and the good collaboration between Indonesia-Malaysia in order to sustain the palm oil industry in Indonesia. Despite the revision of environmental related order, legislation, and implementation, only by 1996 , Indonesia has now lost about 2 million hectares annually $(2$ mil. ha. yr-1) initiated by extreme deforestations and $40 \%$ total lost in total forest coverage in between $1950-2000$ in order to meet timber productions market demand (Rodrigue and Soumonni, 2014).

The situation in Indonesia seems unpredictable especially in palm oil industries where two-thirds of Indonesia's total plantation areas are held by Malaysian and Singaporean companies with total US $\$ 713.6$ million investment (Rahman, 2013). The booming of palm oil sector in Indonesia was driven by three main factors; instability of crude oil price and market (Tan et al. 2009), the crude oil reserves are depleting and finally the palm oil is inexpensive and renewable (Miranowski and Rosburg, 2012). On top of that, the conversions of peat and arable land have their own ramifications. Thus, they are not focusing on deforestation or land clearing for industrial, also it believed that the industrial itself continuously producing the hazardous substances to the ecosystem. For example, the palm oil mill effluent (POME) is known as eutrophic, acidic and content of toxic compounds which could easily pollute the terrestrial and aquatic system (Afriyanti et al. 2016).

\section{Deforestation, Forest Fires, And Atmospheric Pollution}

Indonesia is a unique country with their biological diversity, huge areas of rainforest and also recognized as a largest area of tropical rainforest in the world (FAO, 2010). For the record, Indonesia approximately has 17,800 islands throughout $5,200 \mathrm{~km}$ across the Sunda and Sahul continental shelves (Tsujino et al. 2016). Unluckily, the sorrowful news is lingering Indonesia's ecosystem due to deforestation. According to Hayasaka et al. (2014), Indonesia experienced almost $2 \%$ deforestation annually, corresponding to 1.9 million ha. each year. For the record, Indonesia now is the world's third largest carbon emitter, which $68 \%$ of the emission contributed from deforestation. Whilst, the Southeast Asia's deforestation rate is $1.3 \%$ (or 2.76 million ha.) and those numbers are rapidly growing (Vohland $e t$ al. 2012) due to human aggressiveness and extensiveness to cause unintentionally trans-boundary issues (Miettinen et al. 2016). Two percent $(2 \%)$ could be regarded as invaluable or insignificant in our routine life. But, when we thoroughly dig into environmental perspective, that number might be a precursor to a world's catastrophic. Oh et al. (2015) reported that the air pollution now ranked ninth highest for the global burden disease, and be expecting most serious issues by the year 2050. In 1997/1998, Southeast Asia unprecedentedly blanketed by thick and smoky haze. The haze trespasses the international border without any restrictions, which deliberately triggered by wild and smoldered fire deforestation in Indonesia. The wildfire size was not the only plague in Indonesia, it was even experienced in Cote d'Ivoire in 1982-83 (60,000 ha forest burnt) (Herawati and Santoso, 2011), 3.9 million ha in Brazil in 1998 (Alencar et al. 2006) and even in Brazil, Mexico, Canada, USA, France, Turkey, Greece and Italy as well as the Russian Federation and China's Northeastern Inner Mongolia Autonomous Region (Adams, 2015).

The deforestation is the prolonged subject matter instigated by biomass burning. The terminology use for biomass burning could be diverse, but the deliverable of biomass burning denotation is akin as it has been used long centuries. Biomass burning is solely a growing anthropogenic activity (Rastogi et al. 2014) associate to open burning of existing and dead vegetation (Phairuang et al. 2016) by involving unused vegetative as a vital element (Fujii et al. 2015). Aghamohammadi et al. (2011), by his complexity definition defined biomass burning as a process of producing heat or scientifically terms as exothermic process followed by ignition from reactions between three key elements; sufficient fuel or in biomass context is combustible vegetation, a source of ignition and favorable weather (Herawati and Santoso, 2011). Indonesia, Malaysia, Singapore, Brunei and Southern Thailand were mostly affected by thick, smoky haze caused by an extensive biomass burning (Sahani et al. 2014). For farmers, the biomass burning essentially produced space for their crop plantation, as it beneficial for them in fertilizing their land by using ash as fertilizer, whilst indirectly improved the soil structure, reduce weed competition, and using the chance as to cast away the diseases brought by pest (Budi et al. 2016). Nonetheless, recently fires also have been applied in massive scale by large-scale agricultural scheme in order to reduce the cost. Threaten the diversity and ecosystems (Davies and Unam, 1999) is an aftermath pronounced by endlessly pyrogenic activities such as deforestation (Heriyanto et al. 2015), agricultural residue burning (Kim and Leelasakultum, 2011), slash and burn agriculture (Betha et al. 2013), municipal solid waste (Permadi and Kim Oanh, 2013) and peatswamp conversion (Nurdiana et al. 2016). Literally, biomass burning is related to source of greenhouse gas and aerosol (Vadrevu et al. 2014) attribute to deteriorate visibility and absorbs incident radiation (Abas et al. 2004), producing particulate matter (PM) (Zhang et al. 2015), chemical composition (Ahmed et al. 2016), carbon emission (CO\& CO2) (Mukherjee et al. 2001), and possibly affect the public health (Afroz et al. 2003; Asyikin et al. 2014; Fairos et al. 2016; Raaschounielsen et al. 2016).

Statistically, peatland fire was found demanding to be distinguished. In Indonesia, peatland fires are common (Nara et al. 2011) and nowadays, peat land was characteristically converted to cultivation area. However, without a proper plan, management and implementation, it absolutely indicated an early sign a total failure. For example, Mega Rice Project was once a large cultivation area in central Kalimantan, Indonesia (Forsyth, 2014) and that project now are completely abandoned. As consequences, they left in the drainage of 1 Mha of unmanaged degraded peatlands. For the record, the peat land's forests are reduced $42 \%$ in Equatorial Asia (Peninsular Malaysia, Sumatra and Borneo) by 2007 (Miettinen et al. 2016). The peatlands are highly susceptible to fire as the composition itself formed mostly by the decayed vegetation material. Normally, the peat land burning process involves with low temperature - smoldering fires type (Vadrevu et al. 2014). They are hardly extinguished by extensive rains or even fire-fighting attempts due to heat flux repetitive process through layers, which averagely depths are between $0.5-2.0 \mathrm{~m}$ (Langmann, 2007) and it certainly producing massive particulate matter into the air to form thick of smoke, fog or the worst is haze.

The haze resulting from biomass burning in Borneo, Sumatra, and other parts of SEA has been occurring with increasing frequency, severity, and duration of the last 20 years (Muraleedharan et al. 2000). Traditionally, fire is the effective technique applied to clear forest for agricultural purposes (Reddinton et al. 2014; Langmann, 2007). Just imagine, only a year between of 1982-1983, an estimation of fire burned 3.5 million ha. of East Kalimantan, added with 1 million ha. forest of Sabah was actually equivalent to a total area greater than the size of Switzerland (Salafsky, 1994). The forest fires are not just about the deforestation. The forest fires mean of producing of carbon, particulate and suspended matter and hazardous gaseous to atmospheric level. In Malaysia, $\mathbf{P M}_{10}$ has been identified as an important atmospheric pollutant in major cities (Payus et al. 2013). Scientifically, Total Particulate Matter (TPM), Suspended Particulate Matter (SPM) and Total Suspended Particle (TSP) measurement converted to $\mathrm{PM}_{10}$ (Ostermann and Brauer, 2001). $\mathrm{PM}_{10}$ was not merely originated only by forest fires, but it has been generated roughly by sea spray, road dust, soil, motor vehicle usage, industrial activities, and domestic activities. Instead of studying in $\mathrm{PM}_{10}$, the world now is more interested in $\mathrm{PM}_{2.5}$ and $\mathrm{PM}_{1}$ as the finer size of particulate matter, the higher risk accounted in human's daily life (Permadi and Kim Oanh, 2013; Dholakia et al. 2013; Tan et al. 2016). However, relatively forest fires did account huge contribution on $\mathrm{PM}_{10}$ to transboundary haze pollution and the cases are recurred and worsen since the 1980s (Shaadan et al. 2015).

In 1997, the estimation of carbon, $\mathrm{PM}_{10}$ and aerosol released from forest fires and peatland in Indonesia were $0.81-2.57 \mathrm{Gt}$ and $55 \mathrm{Tg}$ respectively (Mahmud, 2013). Whereas during 2000-2006, the equatorial Asian countries (Indonesia, Malaysia, and Papua New Guinea produced $0.128 \pm 0.051 \mathrm{PgC} \mathrm{yr}-1$, which was corresponding to their fossil combustion (0.148 PgC yr-1) during 2000-2004 (Hamada et al. 2013). Those wild and smoldered fires type were impossible to distinguish. It needs the southward prevailing wind and mixed up with persistent, heavy rain brought by Inter Tropical Convergence Zone helped to distinguish (Huijnen et al. 2016). As been discussed earlier, forest fires are mostly contributed the highest pollution ratio to air 
quality index. But, it depends on a nation's mechanism to encourage their economic structure. As evidence, in small district in Thailand (Chiang Mai) has produced 700 tonnes production of particulate matter, with the forest fires showed the highest contribution with $89 \%$ followed by solid waste burning (5.4\%), all mobile sources $(2.6 \%)$ and agricultural residue burning (2.3\%) (Sillapapiromsuk et al. 2013). In contrast, mobile sources are the highest sources with $70-75 \%$ of total air pollution, followed by stationary sources (20-25\% and open burning sources are only 3-5\% in Malaysia (Rahman, 2013).

\section{EI-Nino Southern Oscillation (ENSO) \& Indian Ocean Dipole (IOD) as exacerbation factor}

The El-Nino Southern Oscillation (ENSO) or commonly known as El-Nino for the public is bizarre weather climate phenomenon, particularly in Southeast Asia. The inter-annual phenomenon is substantially related to increasing in sea surface temperature, thus the rainfall rate over Southeast Asia is decreasing. With decreasing of rainfall, it finally can lead to drought, yet with intensified (Salafsky. 1994) the frequency and magnitude of forest fires (Reddinton et al. 2014). Furthermore, another vital factor contributing to a drier experience in Southeast Asia is Indian Ocean Dipole (IOD). The combination of ENSO and IOD will produce extremely high fire emissions, as for example 1997 forest fires in Kalimantan and Sumatra. Year 1982/83 and 1997/98is the benchmark of major El Nino event, heavily impact on Indonesia's economy (Binternagel et al. 2010), thus it was considered as the strongest of the century, exacerbated by weak prevailing winds coupled with dry conditions along equatorial Pacific and Indian Ocean (Mahmud, 2013; Heil and Goldammer, 2001), explicitly proved that prolonged reduce rainfall, added with experienced of canonical ENSO year over Malaysia-Indonesia region and anomalous easterly winds during August to October may enhance the pyrogenic emission across international border from Kalimantan towards Peninsular Malaysia and Singapore. Whereas, East Asia, an El Nino and IOD event may induce over anomalously rainfall on subsequent summer (Hong et al. 2008). The anomalous climate of ENSO and IOD normally occur when the moisture from sea surfaces are westward transported to the Indian Ocean, resulting in warm water trapped in the eastern Pacific Ocean and western Indian Ocean (Velasco and Rastan, 2015). IOD has a strong dominant on Sea Surface Temperature (SST) and causing fluctuation on monsoonal precipitation on Indian, Asian or even outside Asian's region (Hong et al. 2008). Principally, El Nino events took in a cycle every 2-7 years to recur, but ordinarily not on the interannual basis (Groot et al. 2007). Hong et al. (2008) recently demonstrated the combination of ENSO-IOD was actually differentiated for warm and cold events. If ENSO-IOD events are giving an impact on reducing rainfall rate over Asian region, unfortunately, it completely differs on what happened to Subtropical southern Indian Ocean region. Countries like Mozambique and Madagascar, while islands like Mauritius and Reunion were mostly affected by ENSO-IOD implication. Tropical cyclone genesis is frequently passed through abovementioned locations. But, ENSO, IOD, and another anomalous weather condition; Madden-Julian Oscillation empowered the tropical cyclone magnitude (Ash and Matyas, 2012).

\section{Asean Agreement on Transboundary Haze Pollution (AATHP)}

THE LORAX. An animation movie directed in 2012 by Chris Renaud and Kyle Balda based on Dr. Seuss's book. The story has successfully raised the one and only issue that we are currently facing - "Atmospheric Pollution". Atmospheric pollution may be pronounced as the main threat to humankind. It could be of its own characteristics which easily be transported throughout the rest of the world without any notice, or it even been seen unless it is on a massive scale as discussed earlier. China is one of the countries known to be facing chronic air pollution issues. With the heavily populated, rapid growth of industrialization, and city's development, the major cities in China are totally ruined in the environmental term. In November 2015, BBC (2015) reported that Beijing's residents imported the fresh air from Canada due to endless of bad air quality problem. When all this has happened, the administrative approaches could be best option to be accounted to encounter the related issues. In administrative context, the law and legislative might be the best option to implement. As can be seen, the developed countries (e.g; EU countries) promulgated the stringent environmental law and regulation in order to sustain their ecosystem. In contrast, the developing countries are still enacting the interim laws while the polluter trying to find another way to pollute our country without any repercussion.

ASEAN agreement on Trans-boundary Haze pollution (AATHP) has been established on 10th June 2002 in Kuala Lumpur, Malaysia. The ten ASEAN member signed the framework and it was the first regional arrangement in the world, signed by multilateral that binds together at the national level to mitigate the trans-boundary haze pollution (Haze Action Online, nd). Earlier, ASEAN had drafted and regulated three (3) frameworks plan on issuing the trans-boundary pollution (ASEAN Cooperation Plan on Transboundary Pollution 1995, ASEAN Regional Haze action plan (RHAP) 1997, and ASEAN Zero Burning Policy 2003), before the promulgation of the AATHP. Principally, the agreement was adopt by international customary laws (Principle 21 of the Stockholm Declaration (1972) and Principle 2 of the Rio Declaration (1992), Responsibility of States for Internationally Wrongful Acts (2001), Prevention of Transboundary Harm from Hazardous Activities (2001)), which involving the public policy and management. AATHP comprises of nine (9) sections including the introduction, definition of terms, overall objective, statement of principles, obligations of the signatory states, financial and institutional arrangements for implementing the agreement, obligation of ratification by signatory states and a reference to protocols which detail the procedures of implementation (Jones, 2004). Southeast Asia's transboundary issue was not new to the world. The first ever case regarding trans-boundary air pollution was trail smelter arbitration (1941). Thus, the trail smelter arbitration case has been used since then in the international jurisdiction as a reference in order to resolve any cases related to trans-boundary air pollution. In ASEAN level, the AATHP priority is on giving assistance at national level especially in strategy and planning, institutional and legal frameworks, financing, capacity building, informative management, communications, networking, and stakeholder participation (Nurhidayah, 2012).

Unfortunately, there are a few hurdles are lingering and confronting the ASEAN's initiatives and due to these challenging issues, the ASEAN determination could be seen as a partial disappointment. ASEAN was established by harmonization and cooperativeness among members. In addition, each of ASEAN's members is strongly relying on each other's in term of economic structure, educational, political, and even in the environmental related subject. Thus, the implementation of "ASEAN Way" including consensus, the principles of sensitivity and politeness, non-confrontational approaches to negotiations, behind-thescenes discussions, an emphasis on informal and non-legalistic procedures, non-interference and flexibility (Kim, 2011), makes the framework totally effortless. The AATHP is fundamentally a forum on emphasizing the principle of prevention and monitoring rather than focusing on how to completely mitigate of an endlessly issue and also does not have any precedent for such legal binds. For example, Article 2 (Objective) has stated (Asean, 2002);

"The objective of this Agreement is to prevent and monitor transboundary haze pollution as a result of land and/or forest fires which should be mitigated, through concerted national efforts and intensified regional and international co-operation. This should be pursued in the overall context of sustainable development and in accordance with the provisions of this Agreement."

Whilst in Article 3 (Principle), the AATHP principles basis are on five (5) elementary which are emphasizing on the sovereignty, cooperation and coordination on mitigating, precaution measure on prevent and monitor the haze pollution, manage natural resources and addressing the trans-boundary pollution in every level for ASEAN's member (Asean, 2002). However, the agreement itself does not have any development on civil and legal action onto primarily transboundary polluter. The United Nations Convention on the Law of the Sea (UNCLOS) is multilateral commitments just like as ASEAN's AATHP. Despite choosing diplomatic and negotiated measures as a solution, it also has an international judicial procedure (International Court of Justice or International Tribunal Law of the Sea) would option as well to judge any in compliance by another party. For ASEAN, it 
preferably only by the doctrine of elite politics in ASEAN this would make the environmental framework is bare to be implemented. For some reason, despite framework development, the AATHP seems worthless. For some countries like Indonesia, they are reluctant and unwillingness to ratify, adopt and even to implement just of unreadiness, lack of coordination from government and institutions and sovereignty issues. Just recently, the Philippine and Indonesia have signed the agreement on 2010 and 2014 respectively. Lee et al. (2016) mentioned that Indonesia was the last country to ratify the agreement. Their ratification was only because of exhortation from neighboring countries, especially whom heavily affected by haze. Apart from that, the patronage politics in the Indonesian palm oil plantation is another factor where difficultness element in executing the ASEAN's framework. For Indonesia, it was common practice to appoint "extraeconomic functions" or having "functional directors" despite having a normal organization like been normally practiced by other organization (Gomez, 2009). Their role indirectly meant that the organization decision actually biased by the political parties. With the powerfully organization-political relationship, it could be seen that how ignorance of Indonesian government in the first place in delaying the ratification of the agreement (Varkkey, 2014).

\section{The abatement measures}

The haze which blanketed Southeast Asia in decades was then unprecedented, yet also unpredictable. With an appropriate mitigation plan, it is believed we could save thousand more of land, wildlife, and human life. These might be included the provision of satellite images from Singapore to Indonesia as earlier preventive measure and fire detection as well as in educational campaigns, cooperative works between affected haze pollution countries, and the proper contract clauses in between of authorities and concession licensees (Nichol, 1997). Despite regulating the eco-friendly legislative, appropriate tools and mechanisms to clear land, ban the destructive or inefficient logging practices, redevelop a systematic planning and allocating use rights to forest and encouraging multicultural agricultural practices (Murdiyarso et al. 2004). As been discussed by Brockhaus et al. (2012), despite on focusing in forest economic system, an alternative non-forest involvement could be implemented. Moreover, fire danger rating system could be practical as in developed countries (Canada, Australia, and the United States), which it has been proven for the last 75 years. Fire danger rating is the mechanisms where it could quantifying the potential or ability of a fire to start, spread, and cause damage and it definitely to be installed in forest dealing industries like been practicing in Indonesia (Groot et al. 2007). Finally, the citizen should be informed of the real time of pollutant concentration via electronic quotation boards on the street as it has been installed in Korea for past few years (Lee et al. 2013). This kind of technologies could be as the option to alarm the publics as the technologies are now empowered our social life.

\section{CONCLUSION}

The underlying features of Southeast Asia trans-boundary pollution have been in flux constantly over the past half century. Indonesia right after the colonization of Netherland's era encountered the difficulties such as Java's overpopulated, inadequate of cultivation area, and economic and political instability. Before the 1970s, no such severe deforestations were reported. Until the 1980s, the demands from Northeast Asia's region (Japan and China) coupled by global market drastically increased and finally lead to rapid deforestation. Transboundary pollution may originate by Indonesia's deforestation and forest fires, but unpredictably anomalous weather (El Nino Southern Oscillation and Indian Ocean Dipole) may influence and exacerbated the frequency and magnitude of fires scale. As the only formal regional organization, ASEAN might be the best resolution for Southeast Asia in order to address, mitigate and monitor the transboundary haze pollution across countries. Despite having several lingering issues in ASEAN Agreement on Transboundary Haze Pollution (AATHP), the cooperativeness in regulating, educational, and technologies amongst ASEAN members should be a put as a priority in order to ensure our future environmental sustainability.

\section{ACKNOWLEDGEMENT}

This research is fully supported by University Research Fund (Grant no.: UniSZA/2016/DPU/01). The authors fully acknowledged Universiti Sultan Zainal Abidin for the approved fund which makes this important research viable and effective.

\section{REFERENCES}

Abas, M. R. B., Oros, D. R., and Simoneit, B. R. T. (2004). Biomass burning as the main source of organic aerosol particulate matter in Malaysia during haze episodes. Chemosphere. 55(8): 1089-1095. http://doi.org/10.1016/ j.chemosphere.2004.02.002

Adams, M. A. (2015). Mega-fires, tipping points and ecosystem services: Managing forests and woodlands in an uncertain future. Forest Ecology and Management. 294: 250-261. https://doi.org/10.1016/j.foreco.2012.11.039

Afriyanti, D., Kroeze, C. and Saad, A. (2016). Indonesia palm oil production without deforestation and peat conversion by 2050. Science of the Total Environment, 557-558: 562-570. http://doi.org/10.1016/j.scitotenv.2016.03.032

Afroz, R., Hassan, M. N., and Ibrahim, N. A. (2003). Review of air pollution and health impacts in Malaysia. Environmental Research. 92(2): 71-77. http://doi.org/10.1016/S0013-9351(02)00059-2

Aghamohammadi, N., Nik Sulaiman, N. M., and Aroua, M. K. (2011). Combustion characteristics of biomass in SouthEast Asia. Biomass and Bioenergy. 35(9): 3884-3890. http://doi.org/10.1016/j.biombioe.2011.06.022

Ahmed, M., Guo, X., and Zhao, X. M. (2016). Determination and analysis of trace metals and surfactant in air particulate matter during biomass burning haze episode in Malaysia. Atmospheric Environment. 141: 219-229. http://doi.org/10.1016/j.atmosenv.2016.06.066

Alencar, A., Nepstad, D. C., and Vera-Diaz, M. D. (2006). Forest understory fire in the Brazilian Amazon in ENSO and non-ENSO years: area burned and committed carbon emissions. Earth Interactions. 10(6): 1-17.

ASEAN (2002). ASEAN Agreement on Transboundary Haze Pollution. Retrieved from http://haze.asean.org/asean-agreement-on-transboundaryhaze-pollution/

Ash, K. D., and Matyas, C. J. (2012). The influences of ENSO and the subtropical Indian Ocean Dipole on tropical cyclone trajectories in the southwestern Indian Ocean. International Journal of Climatology. 32(1): 4156. http://doi.org/10.1002/joc.2249

Ashikin, N., Mabahwi, B., Ling, O., Leh, H., Omar, D. (2014). Human health and wellbeing: Human health effect of air pollution. Procedia - Social and Behavioral Sciences. 153: 221-229. http://doi.org/10.1016/j.sbspro.2014.10. 056

As-syakur, A. R., Adnyana, I. W. S., Mahendra, M. S., Arthana, I. W., Merit, I. N., Kasa, I. W., Ekayanti, N. W., Nuarsa, I. W., Sunarta, I. N. (2014). Observation of spatial patterns on the rainfall response to ENSO and IOD over Indonesia using TRMM Multisatellite Precipitation Analysis (TMPA). International Journal of Climatology. 34(15): 3825-3839. http://doi.org/ 10.1002/joc.3939

Ayers, G. P., Peng, L. C., Fook, L. S., Kong, C. W., Gillett, R. W., and Manins, P. C. (2000). Atmospheric concentrations and deposition of oxidised sulfur and nitrogen species at Petaling Jaya, Malaysia, 1993-1998. Tellus, Series B: Chemical and Physical Meteorology. 52(1): 60-73. http://doi.org/ 10.1034/j.1600-0889.2000.00043

Balasubramanian, R. (2003). Comprehensive characterization of PM2.5 aerosols in Singapore. Journal of Geophysical Research. 108(D16): 4523. http://doi.org/10.1029/2002JD002517

BBC. (2015). China Smog: Beijing residents buy fresh air from Canada. Retrieved November 21, 2015, from www.bbc.com/news/world-asia35155357

Betha, R., Pradani, M., Lestari, P., Joshi, U. M., Reid, J. S., Balasubramanian, R. (2013). Chemical speciation of trace metals emitted from Indonesian peat fires for health risk assessment. Atmospheric Research, 122(May 1998): 571578. http://doi.org/10.1016/j.atmosres.2012.05.024

Binternagel, N. B., Juhrbandt, J., Koch, S., Schwarze, S., Barkmann, J., and Faust, H. (2010). Tropical Rainforests and Agroforests under Global Change. Tropical Rainforests and Agroforests under Global Change Ecological and Socioeconomic Valuations. 6: 351-375. http://doi.org/10.1007/978-3-64200493-3

Brockhaus, M., Obidzinski, K., Dermawan, A., Laumonier, Y., Luttrell, C. (2012). An overview of forest and land allocation policies in Indonesia: Is the 
current framework sufficient to meet the needs of REDD+? Forest Policy and Economics. 18: 30-37. http://doi.org/10.1016/j.forpol.2011.09.004

Budi, L., Dharmawan, A. H., Nasdian, F. T., Ramdhoni, S. (2016). Historical forest fire occurrence analysis in Jambi Province during the period of 2000 2015: its distribution \& land cover trajectories. Procedia Environmental Sciences. 33: 450-459. http://doi.org/10.1016/j.proenv.2016.03.096

Casson, A. (2000). The hesitant boom: Indonesia's oil palm sub-sector and political change, 62(29), 1-75. Retrieved from http://www.cifor.org/ publications/pdf_files/CASSON.pdf

Cattau, M. E., Harrison, M. E., Shinyo, I., Tungau, S., Uriarte, M., DeFries, R. (2016). Sources of anthropogenic fire ignitions on the peat-swamp landscape in Kalimantan, Indonesia. Global Environmental Change. 39: 205-219. http://doi.org/10.1016/j.gloenvcha.2016.05.005

Davies, S. J. and Unam, L. (1999). Smoke-haze from the 1997 Indonesian fores fires: Effects on pollution levels, local climate, atmospheric $\mathrm{CO} 2$ concentrations, and tree photosynthesis. Forest Ecology and Management. 124(2-3): 137-144. http://doi.org/10.1016/S0378-1127 (99)00060-2

Demuzere, M., Trigo, R. M., Vila-Guerau de Arellano, J., and van Lipzig, N. P. M. (2008). The impact of weather and atmospheric circulation on O3 and PM10 levels at a mid-latitude site. Atmospheric Chemistry and Physics Discussions. 8: 21037-21088. http://doi.org/10.5194/acpd-8-21037-2008

Department of Environmental, Malaysia. (2015). Haze: Air Pollution Phenomena.

Dholakia, H. H., Purohit, P., Rao, S., Garg, A. (2013). Impact of current policies on future air quality and health outcomes in Delhi, India. Atmospheric Environment. 75: 241-248. http://doi.org/10.1016/j.atmosenv.2013.04.052

Dotse, S. Q., Dagar, L., Petra, M. I., and De Silva, L. C. (2016). Evaluation of national emissions inventories of anthropogenic air pollutants for Brune Darussalam. Atmospheric Environment. 133: 81-92. http://doi.org/10.1016/ j.atmosenv.2016.03.024

Fairos, W., Yaacob, W., Suhana, N., Noor, M., Ili, N., Bakar, C. A., Taib, F. (2016). Journal of Acute Disease, 5(3): 227-231. http://doi.org/10.1016/ j.joad.2016.03.010

FAO. (2010). Global Forest Resources Assessment. Rome.

Field, R. D., Wang, Y., Roswintiarti, O., and Guswanto. (2004). A drought based predictor of recent haze events in western Indonesia. Atmospheric Environment. 38(13): 1869-1878. http://doi.org/10.1016/j.atmosenv.2004.01 011

Forsyth, T. (2014). Public concerns about transboundary haze: A comparison of Indonesia, Singapore, and Malaysia. Global Environmental Change. 25(1) 76-86. http://doi.org/10.1016/j.gloenvcha.2014.01.013

Fujii, Y., Kawamoto, H., Tohno, S., Oda, M., Iriana, W. (2015). Characteristics of carbonaceous aerosols emitted from peatland fire in Riau, Sumatra, Indonesia (2): Identification of organic compounds. Atmospheric Environment. 110: 1-7. http://doi.org/10.1016/j.atmosenv.2015.03.042

Gomez, E. T. (2009). The rise and fall of capital: Corporate Malaysia in historical perspective. Journal of Contemporary Asia. 39(3): 345-381.

Groot, W. J. De, Field, R. D., Brady, M. A., Roswintiarti, O., Mohamad, M. (2007). Development of the Indonesian 465 and Malaysian fire danger rating systems. Mitigation and Adaptation Strategies for Global Change. 12(1): 165-466 180. http://doi.org/10.1007/s11027-006-9043-8

Hamada, Y., Darung, U., Limin, S. H., Hatano, R. (2013). Characteristics of firegenerated gas emission observed during a large peatland fire in 2009 at Kalimantan, Indonesia. Atmospheric Environment. 74: 177-181. http://doi.org/10.1016/j.atmosenv.2013.03.058

Hayasaka, H., Noguchi, I., Putra, E. I., Yulianti, N., Vadrevu, K. (2014). Peatfire-related air pollution in Central Kalimantan, Indonesia. Environmental Pollution. 195: 257-266. http://doi.org/10.1016/j.envpol.2014.06.031

Haze Action Online. (n.d.) ASEAN on Agreement Tranboundary Haze Pollution. Retrieved November 8, 2016, from http://haze.asean.org/asean-agreement-ontransboundary-haze-pollution/

Heil, A., and Goldammer, J. G. (2001). Smoke-Haze Pollution: A Review of the 1997 Episode in Southeast Asia. Regional Environment Change. 2: 24-37 http://doi.org/10.1007/s101130100021.

Herawati, H., and Santoso, H. (2011). Tropical forest susceptibility to and risk of fire under changing climate: A review of fire nature, policy and institutions in Indonesia. Forest Policy and Economics. 13(4): 227-233. http://doi.org/ 10.1016/j.forpol.2011.02.006

Heriyanto, E., Syaufina, L., Sobri, M. (2015). Forecasting Simulation of Smoke Dispersion from Forest and Land Fires in Indonesia. Procedia Environmental Sciences. 24: 111-119. http://doi.org/10.1016/j.proenv.2015.03.015

Hong, C.-C., Lu, M.-M., and Kanamitsu, M. (2008). Temporal and spatial characteristics of positive and negative Indian Ocean dipole with and without ENSO. Journal of Geophysical Research. 113(D8): 1-15. http://doi.org/ 10.1029/2007JD00915

Hu, G. P., Balasubramanian, R., Wu, C. D. (2003). Chemical characterization of rainwater at Singapore. Chemosphere. 51(8): 747-755. http://doi.org/ 10.1016/S0045-6535 (03)00028-6

Huijnen, V., Wooster, M. J., Kaiser, J. W., Gaveau, D. L. A., Flemming, J., Parrington, M., Inness, A.,Murdiyarso, D.,Main, B., and van Weele, M.
(2016). Fire carbon emissions over maritime Southeast Asia in 2015 largest since 1997. Scientific Reports. 6: 26886. http://doi.org/10.1038/srep26886

Hyer, E. J., and Chew, B. N. (2010). Aerosol transport model evaluation of an extreme smoke episode in Southeast Asia. Atmospheric Environment. 44(11): 1422-1427. http://doi.org/10.1016/j.atmosenv.2010.01.043

Jones, D. S. (2004). ASEAN Initiatives to combat haze pollution: An assessment of regional cooperation in public policy-making. Asian Journal of Political Science. 12(2): 59-77.

Kartawinata, K., Riswan, S., Gintings, A.N., and Puspitojati, T. (2001). An overview of post-extraction secondary forests in Indonesia. Journal of Tropical Forest. 13(4): 621-638.

Keywood, M. D., Ayers, G. P., Gras, J. L., Boers, R., and Leong, C. P. (2003). Haze in the Klang Valley of Malaysia. Atmospheric Chemistry and Physics Discussions. 3(1): 615-653. http://doi.org/10.5194/acpd-3-615-2003

Kim, C. H., Park, S. Y., Kim, Y. J., Chang, L. S., Song, S. K., Moon, Y. S., Song, C. K. (2012). A numerical study on indicators of long-range transport potential for anthropogenic particulate matters over northeast Asia Atmospheric Environment. 58: 35-44. http://doi.org/10.1016/j.atmosenv. 2011.11.002

Kim, M. (2011). Theorizing ASEAN integration. Asian Perspectives. 35(35): 407-435.

Kim, O, N. T., and Leelasakultum, K. (2011). Analysis of meteorology and emission in haze episode prevalence over mountain-bounded region for early warning. Science of the Total Environment. 409(11): 2261-2271. http://doi.org/10.1016/j.scitotenv.2011.02.022

Koe, L. C. C., Arellano, A. F., McGregor, J. L. (2001). Investigating the haze transport from 1997 biomass burning in Southeast Asia: Its impact upon Singapore. Atmospheric Environment. 35(15): 2723-2734. http://doi.org/10.1016/S1352-2310 (00)00395-2

Langmann, B. (2007). A model study of smoke-haze influence on clouds and warm precipitation formation in Indonesia 1997/1998. Atmospheric Environment. 41(32): 6838-6852. http://doi.org/10.1016/j.atmosenv.2007.04. 050

Lee, J. S. H., Jaafar, Z., Tan, A. K. J., Carrasco, L. R., Ewing, J. J., Bickford, D. P., Web, E. L., Koh, L. P. (2016). Toward clearer skies: Challenges in regulating transboundary haze in Southeast Asia. Environmental Science and Policy. 55: 87-95. http://doi.org/10.1016/j.envsci.2015.09.008

Lee, K. H., Kim, Y. J., Kim, M. J. (2006). Characteristics of aerosol observed during two severe haze events over Korea in June and October 2004. Atmospheric Environment. 40(27): 5146-5155. http://doi.org/10.1016/ j.atmosenv.2006.03.050

Lee, S., Ho, C., Gon, Y., Choi, H., Song, C. (2013). Influence of transboundary air pollutants from China on the high- PM 10 episode in Seoul, Korea for the period October 16 L 20, 2008. Atmospheric Environment. 77: 430-439. http://doi.org/10.1016/j.atmosenv.2013.05.006

Lin, N. H., Sayer, A. M., Wang, S. H., Loftus, A. M., Hsiao, T. C., Sheu, G. R., Hsu, N. C., Tsay, S. C. Chantara, S. (2014). Interactions between biomassburning aerosols and clouds over Southeast Asia: Current status, challenges, and perspectives. Environmental Pollution. 195: 292-307. http://doi.org/ 10.1016/j.envpol.2014.06.036

Mahmud, M. (2013). Assessment of atmospheric impacts of biomass open burning in Kalimantan, Borneo during 2004. Atmospheric Environment, 78: 242-249. http://doi.org/10.1016/j.atmosenv.2012.03.019

Miettinen, J., Shi, C., and Liew, S. C. (2016). Land covers distribution in the peatlands of Peninsular Malaysia, Sumatra and Borneo in 2015 with changes since 1990. Global Ecology and Conservation. 6: 67-78. http://doi.org/ 10.1016/j.gecco.2016.02.004

Miranowski, J., and Rosburg, A., (2012). Long-term biofuel projections under different oil price scenarios. Agricultural Bio Forum. 16(1): 9.

Mukherjee, P., and Viswanathan, S. (2001). Contributions to CO concentrations from biomass burning and traffic during haze episodes in Singapore. Atmospheric Environment. 35(4): 715-725. http://doi.org/10.1016/S1352-535 2310(00)00286-7

Muraleedharan, T. R., Radojevic, M., Waugh, A., Caruana, A. (2000). Chemical characterisation of the haze in Brunei Darussalam during the 1998 episode. Atmospheric Environment. 34(17): 2725-2731. http://doi.org/10.1016/ S1352-2310(99)00341-6

Murdiyarso, D., Lebel, L., Gintings, A. N., Tampubolon, S. M. H., Heil, A., Wasson, M. (2004). Policy responses to complex environmental problems: Insights from a science-policy activity on transboundary haze from vegetation fires in Southeast Asia. Agriculture, Ecosystems and Environment. 104(1): 47-56. http://doi.org/10.1016/j.agee.2004.01.005

Nara, H., Tanimoto, H., Nojiri, Y., Mukai, H., Machida, T., and Tohjima, Y. (2011). On board measurement system of atmospheric carbon monoxide in the Pacific by voluntary observing ships. Atmospheric Measurement Tehnology. 4(11), 2495-2507.

Nichol, J. (1997). Bioclimatic impacts of the 1994 smoke haze event in Southeast Asia. Atmospheric Environment. 31(8): 1209-1219. http://doi.org/ 10.1016/S1352-2310 (96)00260-9 
Norela, S., Saidah, M. S., and Mahmud, M. (2013). Chemical composition of the haze in Malaysia 2005. Atmospheric Environment. 77: 1005-1010. http://doi.org/10.1016/j.atmosenv.2013.05.024

Nurdiana, A., Setiawan, Y., Pawitan, H., Budi, L., Ayu, P. (2016). Land changes monitoring using MODIS time-series imagery in peat lands areas, Muaro Jambi, Jambi Province, Indonesia. Procedia Environmental Sciences. 33: 443-449. http://doi.org/10.1016/j.proenv.2016.03.095

Nurhidayah, L. (2012). AsianSIL Working Paper 2012 / 12 The Influence of International Law upon ASEAN Approaches in Addressing Transboundary Haze Pollution in the ASEAN Region, (February).

Oh, H., Ho, C., Kim, J., Chen, D., Lee, S., Choi, Y., Chang, L., and Song, C. (2015). Long-range transport of air pollutants originating in China : A possible major cause of multi-day high-PM 10 episodes during cold season in Seoul, Korea. Atmospheric Environment. 109: 23-30. http://doi.org/10.1016/j.atmosenv.2015.03.005

Ostermann, K., and Brauer, M. (2001). Air quality during haze episodes and its impact on health. Forest Fires and Regional Haze in Southeast Asia. 41-66.

Palanissamy, A. (2013). Haze Free Air in Singapore and Malaysia - The Spirit of the Law in South East Asia. International Journal of Education and Research. 1(8): 1-8.

Park, S.-U., Cho, J.-H. Park, M.S. (2013). Identification of Visibility Reducing Weather Phenomena Due to Aerosols. Environmental Management and Sustainable Development. 2(1): 126-142. http://doi.org/10.5296/emsd.v2i1. 3628

Payus, C., Abdullah, N., and Sulaiman, N. (2013). Airborne Particulate Matter and Meteorological Interactions during the Haze Period in Malaysia. International Journal of Environmental Science and Development. 4(4): 398402. http://doi.org/10.7763/IJESD.2013.V4.380

Permadi, D. A., and Kim Oanh, N. T. (2013). Assessment of biomass open burning emissions in Indonesia and potential climate forcing impact Atmospheric Environment. 78: 250-258. http://doi.org/10.1016/j.atmosenv. 2012.10.016

Phairuang, W., Hata, M., and Furuuchi, M. (2016). ScienceDirect Influence of agricultural activities, forest fires and agro-industries on air quality in Thailand. JES. 1-13. http://doi.org/10.1016/j.jes.2016.02.007

Raaschou-nielsen, O., Beelen, R., Wang, M., Hoek, G., Andersen, Z. J., Hoffmann, B., (2016). Particulate matter air pollution components and risk for lung cancer. Environment International, 87: 66-73. http://doi.org/10.1016/ j.envint.2015.11.007

Rahman, H. A. (2013). Haze Phenomenon in Malaysia: Domestic or Transboudry Factor? 3rd International Journal Conference on Chemical Engineering and Its Applications. 597-599.

Rastogi, N., Singh, A., Singh, D., Sarin, M. M. (2014). Chemical characteristics of PM2.5 at a source region of biomass burning emissions: Evidence for secondary aerosol formation. Environmental Pollution. 184: 563-569. http://doi.org/10.1016/j.envpol.2013.09.037

Reddington, C. L., Yoshioka, M., Balasubramanian, R., Ridley, D., Toh, Y. Y., Arnold, S. R., Spracklen, D. V. (2014). Contribution of vegetation and peat fires to particulate air pollution in Southeast Asia. Environmental Research Letters. 9(9): 94006. http://doi.org/10.1088/1748-9326/9/9/094006

Rein, G., Cohen, S., and Simeoni, A. (2009). Carbon emissions from smouldering peat in shallow and strong fronts. Proceedings of the Combustion Institute. 32 II(2:, 2489-2496. http://doi.org/10.1016/j.proci.2008.07.008

Rodrigue, J., and Soumonni, O. (2014). Deforestation, foreign demand and export dynamics in Indonesia. Journal of International Economics. 93(2): 316-338. http://doi.org/10.1016/j.jinteco.2014.03.004

Ryu, S. Y., Kwon, B. G., Kim, Y. J., Kim, H. H., and Chun, K. J. (2007). Characteristics of biomass burning aerosol and its impact on regional air quality in the summer of 2003 at Gwangju, Korea. Atmospheric Research 84(4): 362-373. http://doi.org/10.1016/j.atmosres.2006.09.007

Sahani, M., Zainon, N. A., Wan Mahiyuddin, W. R., Latif, M. T., Hod, R., Khan, M. F., Tahir, N. M., Chan, C. C. (2014). A case-crossover analysis of forest fire haze events and mortality in Malaysia. Atmospheric Environment. 96: 257-265. http://doi.org/10.1016/j.atmosenv.2014.07.043

Salafsky, N. (1994). Drought in the rainforest: Effect of the 1991 El-Nino Southern Oscillation event on a rural economy in west Kalimantan, Indonesia. Journal of Climatic Change, 1991(27): 373-396.

Shaadan, N., Jemain, A. A., Latif, M. T., Deni, S. M. (2015). Anomaly detection and assessment of PM10 functional data at several locations in the Klang
Valley, Malaysia. Atmospheric Pollution Research. 6(2): 365-375. http://doi.org/10.5094/apr.2015.040

Shi, H., Wang, Y., Chen, J., and Huisingh, D. (2015). Preventing smog crises in China and globally. Journal of Cleaner Production. 112: 1261-1271. http://doi.org/10.1016/j.jclepro.2015.10.068

Sillapapiromsuk, S., Chantara, S., Tengjaroenkul, U., Prasitwattanaseree, S., and Prapamontol, T. (2013). Determination of PM10 and its ion composition emitted from biomass burning in the chamber for estimation of open burning emissions. Chemosphere. 93(9): 1912-1919. http://doi.org/10.1016/ j.chemosphere.2013.06.071

Soleiman, A., Othman, M., Samah, A. a., Sulaiman, N. M., and Radojevic, M. (2003). The Occurrence of Haze in Malaysia: A Case Study in an Urban Industrial Area. Pure and Applied Geophysics. 160(1-2): 221-238. http://doi.org/10.1007/s00024-003-8774-7

Sunderlin, W.D., and Resosudarmo, I. A. P. (1996). Rates and causes of deforestation in Indonesia: Towards a resolution of the ambiguities. Retrieved from http://www.cifor.org/publications/pdf_files/OccPapers/OP09n.pdf

Tacconi, L., and Vayda, A. P. (2006). Slash and burn and fires in Indonesia: A comment. Ecological Economics. 56: 1-4. http://doi.org/10.1016/j.ecolecon. 2005.03.034

Tan, J., Duan, J., Zhen, N., He, K., Hao, J. (2016). Chemical characteristics and source of size-fractionated atmospheric particle in haze episode in Beijing. Atmospheric Research. 167: 24-33. http://doi.org/10.1016/j.atmosres. 2015.06.015

Tan, K.T., Lee, K.T., Mohamed, A.R., and Bhatia, S. (2009). Palm oil: addressing issues and towards sustainable development. Renewable Sustainable Energy Rev. 13(2): 420-427.

Tsujino, R., Yumoto, T., Kitamura, S., Djamaluddin, I., and Darnaedi, D. (2016). History of forest loss and degradation in Indonesia. Land Use Policy. 57: 335347. http://doi.org/10.1016/j.landusepol.2016.05.034

Vadrevu, K. P. rasad, Ohara, T., and Justice, C. (2014b). Air pollution in Asia. Environmental Pollution. 195, 233-235. http://doi.org/10.1016/j.envpol. 2014.09.006

Vadrevu, K. P., Lasko, K., Giglio, L., Justice, C. (2014a). Analysis of Southeast Asian pollution episode during June 2013 using satellite remote sensing datasets. Environmental Pollution. 195: 245-256. http://doi.org/10.1016/ j.envpol.2014.06.017

Van der Werf, G. R., Dempewolf, J., Trigg, S. N., Randerson, J. T., Kasibhatla, P. S., Giglio, L. (2008). Climate regulation of fire emissions and deforestation in equatorial Asia. Proceedings of the National Academy of 625 Sciences of the United States of America. 105(51): 20350-5. http://doi.org/ 10.1073/pnas.0803375105

Varkkey, H. (2014). Regional cooperation, patronage and the ASEAN Agreement on transboundary haze pollution. International Environmental Agreements: Politics, Law and Economics. 14(1): 65-81. http://doi.org/ 10.1007/s10784-013-9217-2

Velasco, E., and Rastan, S. (2015). Air quality in Singapore during the 2013 smoke-haze episode over the Strait of Malacca: Lessons learned. Sustainable Cities and Society. 17: 122-131. http://doi.org/10.1016/j.scs.2015.04.006

Vohland, K., Walz, A., Popp, A., Lotze-campen, H., Cramer, W. (2012). Climate Change, Justice and Sustainability. Climate Change, Justice and Sustainability: Linking Climate and Development Policy. 179-191. http://doi.org/10.1007/978-94-007-4540-7

Wang, H., Tan, S. C., Wang, Y., Jiang, C., Shi, G. Yu, Zhang, M. X., Che, H. Z. (2014). A multisource observation study of the severe prolonged regional haze episode over eastern China in January 2013. Atmospheric Environment. 89: 807-815. http://doi.org/10.1016/j.atmosenv.2014.03.004

Wiwatanadate, P., and Liwsrisakun, C. (2011). Acute effects of air pollution on peak expiratory flow rates and symptoms among asthmatic patients in Chiang Mai, Thailand. International Journal of Hygiene and Environmental Health. 214(3): 251-257. http://doi.org/10.1016/j.ijheh.2011.03.003

Zaccone, C., Rein, G., Orazio, V. D., Hadden, R. M., Belcher, C. M., Miano, T. M. (2014). Smouldering fire signatures in peat and their implications for palaeoenvironmental reconstructions. Geochimica et Cosmochimica Acta. 137: 134-146. http://doi.org/10.1016/j.gca.2014.04.018

Zhang, Q., Yan, R., Fan, J., Yu, S., Yang, W., Li, P., Wang, S., Chen, B., Liu, W., and Zhang, X. (2015). A heavy haze episode in Shanghai in December of 2013: Characteristics, origins and implications. Aerosol and Air Quality Research. 15(5): 1881-1893. http://doi.org/10.4209/aaqr.2015.03.0179. 